\title{
ANALISIS PENDAYAGUNAAN KARUNIA-KARUNIA ROH TERHADAP PERTUMBUHAN JEMAAT GEREJA PANTEKOSTA di INDONESIA EL-SHADDAI MAKASSAR
}

\author{
Johny Sumarauw $w^{1)}$, Made Astika ${ }^{2) *}$ \\ ${ }^{1)}$ Alumni Pascasarjana Prodi Teologi Sekolah Tinggi Theologia Jaffray \\ ${ }^{2)}$ Dosen Pascasarjana Prodi Teologi Sekolah Tinggi Theologia Jaffray \\ ${ }^{*}$ Penulis korespondensi: made.astika@sttjaffray.ac.id
}

\begin{abstract}
Abstrak
Pendayagunaan karunia-karunia Roh terhadap pertumbuhan jemaat memiliki dampak pada pertumbuhan gereja secara kuantitas dan kualitas. Penelitian ini dilaksanakan di Gereja Pantekosta di Indonesia (GPdI) El-Shaddai Makassar dengan tujuan melihat pengaruh pendayagunaan karunia-karunia Roh terhadap pertumbuhan gereja secara kuantitas dan kualitas melalui riset lapangan terhadap jemaat lokal. Kesimpulan penelitian ini adalah: Pertama, pendayagunaan karunia-karunia Roh yang dimiliki oleh setiap orang percaya memiliki satu atau lebih karunia, suatu strategi diperlukan untuk memperkenalkan karunia-karunia Roh melalui khotbah, ceramah, pendalaman Alkitab, sehingga mereka meyakini dan memercayai bahkan dapat menemukan karunianya, kemudian dikelompokkan dalam satu kelompok semua yang memiliki karunia sejenis, dibina, dilatih dan akhirnya ditempatkan pada pelayanan yang sesuai dengan karunianya. Selain itu, faktor-faktor penunjang pelaksanaan strategis pendayagunaan karunia-karunia Roh adalah organisasi yang mantap, menerapkan bimbingan dalam jemaat, dalam hal ini karuniakarunia Roh, serta ketersediaan keuangan, alat-alat dan lapangan pelayanan yang tersedia.
\end{abstract}

Kata kunci: pendayagunaan, karunia, Roh Kudus, Pantekosta, gereja

The utilization of the gifts of the Spirit for the growth of the church has an impact on church growth in both quantity and quantity. The research for this article was conducted at the El-Shaddai Church in Makassar of the Pentecostal Church of Indonesia with the purpose of seeing the effect of the utilization of the gifts of the Spirit for both quantitative and qualitative church growth through field research in the local congregation. The conclusions of this study are: First, for the utilization of the gifts of the Spirit, of which every believer has one or more, a strategy is needed that introduces the gifts of the Spirit through sermons, lectures, and Bible studies so that they believe and trust that they can find their gift(s). Then they are put in a group together with those that possess the same gift where they are nurtured, trained, and finally they are placed in a ministry in accordance with their gifts. In addition, the supporting 
factors of a strategic implementation of the utilization of the gifts of the Spirit are a solid organizational structure, application of nurturing in the church (in this case the gifts of the Spirit), and the availability of finances, equipment, and a place of ministry.

Keywords: utilization, gift, Holy Spirit, Pentecostal, church

\section{Pendahuluan}

Memenangkan jiwa bagi Kristus merupakan tujuan gereja dalam dunia ini, sehingga di dalam mencapai tujuan tersebut tidak sedikit cara yang digunakan oleh para pemimpin gereja untuk mengembangkan gereja antara lain, mengirim utusan-utusan untuk mengikuti seminarseminar pertumbuhan gereja, mengundang secara khusus pembicarapembicara bertaraf nasional dan internasional untuk mengadakan seminar dan kebaktian kebangunan rohani dan sebagainya. Cara-cara yang disebutkan di atas adalah baik dan tidak salah, namun apabila berhitung secara ekonomis maka cara-cara ini membutuhkan biaya yang cukup besar, sehingga sukar dijangkau oleh jemaat-jemaat yang berpenghasilan rendah. Namun demikian selain yang disebutkan di atas, ada pula cara lain, yang sering dilupakan, dan diabaikan oleh para pemimpin jemaat yaitu menggali dan memanfaatkan potensi yang ada dalam jemaat itu sendiri.

Potensi dalam jemaat yang penulis maksudkan adalah "karuniakarunia Roh" yang telah diberikan oleh Allah kepada jemaat untuk mengembangkan jemaat itu sendiri. Hal ini sesuai dengan pernyataan Yakob Tomatala sebagai berikut, "Untuk melaksanakan penatalayanan gereja, Kristus telah melengkapkan gereja dengan karunia-karunia rohani untuk melaksanakan penatalayanan Allah di dalam dan melalui gereja." Pernyataan Melvin Hodges dan Ralph Williams mengatakan, "Jemaat telah dilengkapi oleh Allah dengan kemampuan yang perlu dan karunia-karunia yang menyanggupkan bertumbuh."

Pernyataan di atas, maka penulis menyimpulkan bahwa di dalam gereja atau jemaat, Allah telah memberikan karunia-karunia Roh untuk melaksanakan tugas di dalam dan melalui gereja untuk pertumbuhan jemaat itu sendiri. Namun karunia-karunia Roh dalam jemaat dewasa ini kurang didayagunakan, sehingga tidak sedikit anggota jemaat menjadi pasif, dan mengakibatkan pertumbuhan mengalami hambatan. Hal ini mungkin disebabkan karena ketidaktahuan pemimpin-pemimpin jemaat

\footnotetext{
${ }^{1}$ Yakob Tomatala, Penatalayanan Gereja yang Efektif di Dunia Modern, Cetakan pertama (Malang: Gandum Mas, 1987), 18.

${ }^{2}$ Melvin L. Hodges dan Ralph D. Williams, Sidang Jemaat Yang Berkembang (Malang: Gandum Mas, 1962), 17.
} 
tentang karunia-karunia Roh, sehingga membatasi keefektifan jemaat dalam melayani.

\section{Peter Wagner mengatakan:}

Ketidaktahuan akan karunia-karunia Roh boleh jadi merupakan penyebab utama bagi terbelakangnya pertumbuhan gereja dewasa ini. Mungkin hal ini merupakan sebab dari sebagian besar keputusan, ketidakmantapan, frustrasi, dan rasa bersalah yang mengganggu banyak orang Kristen serta membatasi keefektifan sepenuhnya bagi Allah. ${ }^{3}$

Selain ketidaktahuan tentang karunia-karunia Roh, juga dibayangi dengan praktik-praktik yang salah dalam pendayagunaan karuniakarunia Roh, sehingga tidak dikembangkan. Kebenaran ini diungkapkan oleh G. Lindsay sebagai berikut:

Satu keadaan yang menahan sebagian orang akan mencari karunia-karunia Rohul Kudus ialah takut akan setan. Mereka melihat kuasa setan-setan dan tipunya di mana-mana. Tentu, kita mengetahui bahwa ada banyak roh-roh penipu di dalam dunia. Karena itu, Kitab Suci memberi kita anjuran untuk menguji segala roh dan membedakan yang tidak berasal dari Allah (1 Yohanes 4:l-3). Lagi pula, satu di antara karunia-karunia itu ialah membedakan segala roh, karunia itu sengaja mengetahui kehadiran kuasakuasa jahat. ${ }^{4}$

Ada gereja yang sama sekali tidak mengakui lagi adanya karuniakarunia Roh dengan mengatakan bahwa karunia-karunia Roh yang ditulis dalam Perjanjian Baru hanya berlaku di zaman dahulu, atau dengan kata lain bahwa karunia-karunia Roh tidak dibutuhkan lagi. Stephen Lang mengatakan dalam bukunya, 1001 Hal yang Ingin Anda Ketahui tentang Roh Kudus sebagai berikut:

Agustine menjadi uskup di kota Hippo, Afrika utara. Agustine percaya bahwa karunia-karunia Roh Kudus memang bekerja di tengah jemaat mula-mula, tetapi segera setelah iman Kristen ditetapkan (dan dituliskan dalam Alkitab untuk selamanya), karunia-karunia ini tidak lagi dibutuhkan. Dia menentang bahasa Roh dan mengaitkannya dengan orang

\footnotetext{
${ }^{3}$ C. Peter Wagner, Manfaat Karunia Roh, cetakan kelima (Malang: Gandum Mas, 2005), 22.

${ }^{4}$ Gordon Kindsay, Segala Sesuatu Tentang Karunia-karunia Rohul Kudus, cetakan ketiga (Jakarta: YPII, 1982), 9.
} 
kafir yang kalut, yang berbahasa Roh, bernubuat, dan mengaku melakukan mukjizat.

Berbeda dengan pendapat Rick Warren yang mengatakan,

Ia mengharapkan setiap orang Kristen menggunakan karunia dan telentanya dalam pelayanan. Jika kita dapat membangunkan dan melepaskan talenta, sumber kemampuan, kreativitas dan energi yang besar yang selama ini tidak aktif dalam gereja lokal yang khas, kekristenan akan mengalami ledakan angka pertumbuhan yang tidak pernah terjadi sebelumnya. ${ }^{6}$

Hal ini menunjukkan suatu kelemahan dan kerugian besar bagi suatu gereja yang tidak mempraktikkan karunia-karunia Roh dalam jemaat, dengan demikian pertumbuhan jemaat akan mengalami hambatan.

Pendayagunaan karunia-karunia Roh terhadap pertumbuhan jemaat memiliki dampak pada pertumbuhan gereja secara kuantitas dan kualitas. Penelitian ini dilaksanakan di Gereja Pantekosta di Indonesia (GPdI) El-Shaddai Makassar dengan tujuan melihat pengaruh pendayagunaan karunia-karunia Roh terhadap pertumbuhan gereja secara kuantitas dan kualitas melalui riset lapangan terhadap jemaat lokal.

\section{Konsep Alkitab tentang Karunia-Karunia Roh}

Adapun bagian-bagian yang memuat mengenai karunia-karunia Roh dalam Perjanjian Baru secara khusus dalam Kitab Roma 12, Paulus pertama-tama menggambarkan jemaat sebagai tubuh Kristus (ayat 4-5) dan setelah itu Paulus mengemukakan karunia-karunia yang berlainlainan yang dimiliki oleh orang percaya (ayat 6-8). Kitab Roma, Paulus mengemukakan pembahasannya tentang karunia-karunia yang lebih panjang dalam 1 Korintus 12-14. Karunia-karunia Roh adalah kebenaran yang tidak perlu diragukan, melainkan perlu mendapat perhatian khusus dari orang-orang percaya untuk lebih jauh melihat konsep yang diberikan oleh Alkitab mengenai karunia-karunia Roh.

\footnotetext{
${ }^{5}$ J. Stephen Lang, 1001 Hal yang Ingin Anda Ketahui tentang Roh Kudus, cetakan pertama (Jakarta: YPI Imanuel, 2002), 127.

${ }^{6}$ Rick Warren, Pertumbuhan Gereja Masa Kini, cetakan keempat (Malang: Gandum Mas, 2003), 373-374.
} 
Oleh karena itulah, maka dalam kesempatan ini penulis dapat memberikan beberapa konsep yang diberikan oleh Alkitab mengenai karunia-karunia Roh yakni:

\section{Pengertian Karunia-Karunia Roh}

Istilah Karunia Roh adalah perpaduan dari dua kata yakni "karunia" dan "Roh." Kedua kata ini terpisah, namun karena karunia berasal dari Roh Kudus sehingga disatukan menjadi karunia Roh, sehingga menjadi suatu ungkapan. Misalnya dalam 1 Korintus 12:1 terjemahan bahasa Indonesia "karunia-karunia Roh" dan di dalam terjemahan bahasa Inggris "spiritual gifts," namun dalam bahasa Yunani disebut "pneumatikos."

Kata yang digunakan dalam 1 Korintus 12:1 untuk karunia-karunia Roh adalah pneumatika. Menurut buku The Greek New Testament Dictionary mengatakan bahwa "kata pneumatikos artinya Spiritual, pertaining to the spirit; Spiritual person; Spiritual thing; spiritual gift; Supernatural or spiritual." Dalam 1 Korintus 12:4, kata yang digunakan untuk "karunia-karunia Roh" adalah charisma. Menurut W.E. Vine mengatakan bahwa "kata Charisma adalah a gift of grace, a gift involving grace (charis) on the part of God as the Donor, is used ... of His endowments upon believers by the operation of the Holy Spirit in the churches (Rom. 12:6;1 Kor. 12:4, 9, 28,30,31)."

Mark W. Christy mengumpulkan beberapa definisi mengenai kata charisma. Menurut James F. Stitzinger, kata charisma selalu dikaitkan dengan karunia-karunia Roh. Sekitar 50 kali menurut G. D. Fee, kata charisma pada berbagai cara kasih karunia Allah yang telah dibuktikan di antara umat-Nya. Hal ini mencakup karunia-karunia beragam termasuk kehidupan kekal (Rom. 6:23;5:15, 16), hak-hak istimewa khusus yang diberikan kepada Israel (Rom. 11:29, mengacu pada Rom. 9:4-5), selibat dan perkawinan (1 Kor. 7:7), pembebasan dari bahaya kematian (2 Kor. $1: 10)^{9}$

Dengan memerhatikan beberapa penjelasan di atas, maka dapat disimpulkan bahwa sekalipun menggunakan istilah-istilah yang tidak sama, tetapi mempunyai sumber yang sama, maksud yang sama serta pengertian sama yaitu suatu pemberian dari Allah untuk umat-Nya dan digunakan dalam pelayanan bagi orang-orang percaya.

\footnotetext{
${ }^{7}$ Kurt Aland, eds. et al., The Greek New Testament Dictionary (West Germany: BibliaDruck Gmbh Stuttgart, 1983), 145.

${ }^{8}$ W. E. Vine, The Expanded Vine's Expository Dictionary of New Testament Words (Minnesota: Bethany House Publishers, 1984), 477.

${ }^{9}$ Mark W. Christy, "Spiritual Gifts and Church Growth" (Southwestern Baptist Theological Seminary, 2009), 2, diakses 25 Januari 2015, http://storage.cloversites.com/ midcitiescommunitychurch/documents/SPIRITUAL\%20GIFTS\%20AND\%20CHURC H\%20GROWTH_2.pdf.
} 
Untuk mendapatkan pemahaman yang lengkap tentang karuniakarunia Roh, maka dalam bagian ini penulis mengemukakan beberapa definisi tentang karunia-karunia Roh sebagaimana dikemukakan oleh beberapa penulis, antara lain:

John Stott mengatakan, "Karunia-karunia Roh adalah kecakapankecakapan tertentu, yang diberikan oleh kasih karunia dan kuasa Allah, yang mencakapkan orang bagi pelayanan yang khusus dan sesuai.,10

Scheunemann memberikan definisi tentang karunia-karunia Roh sebagai berikut:

Karunia-karunia Roh dapat juga dinamakan "pemberian-pemberian anugerah", karena kata charisma berakar pada kata charis, yang berarti anugerah atau kasih karunia. Charis Allah menerbitkan beraneka ragam charismata. Dalam kehidupan umat Israel, charismata itu mula-mula berarti hak-hak istimewa yang dikaruniakan oleh Allah kepada mereka. Kemudian dalam Perjanjian Baru, charismata itu mencakup milik rohani orang percaya, yaitu anugerah keselamatan dan kehidupan yang kekal, serta perlengkapan Roh Kudus secara khusus. ${ }^{11}$

Oswald Sanders mengatakan, "Pneumatika dan charismata diartikan bersama-sama, menandakan kuasa dan pemberian-pemberian Roh Kudus yang luar biasa yang dianugerahkan-Nya kepada orang-orang percaya selaku perlengkapan untuk pengabdian Kristen dan untuk meneguhkan iman dari Gereja." ${ }^{21}$

Abineno menuliskan, "Kharisma-kharisma itu adalah pemberianpemberian Tuhan, karena kasih-Nya, dianugerahkan kepada anggotaanggota jemaat. Dengan perkataan lain bahwa kharisma-kharisma itu bukan upah atau semacam balasan untuk kebaikan atau prestasi mereka." ${ }^{13}$

Peter Wagner menuliskan, "Sebuah karunia Roh adalah perlengkapan istimewa yang diberikan oleh Roh Kudus kepada tiap-tiap anggota dalam Tubuh Kristus menurut kasih karunia Allah untuk dipakai dalam konteks Tubuh itu." ${ }^{, 14}$

Jadi berdasarkan beberapa definisi tersebut di atas, maka dapat ditarik beberapa simpulan sebagai berikut:

\footnotetext{
${ }^{10}$ John, R.W. Stott, Baptisan dan Kepenuhan (Jakarta: BPK Gunung Mulia, 1984), 80.

${ }^{11}$ D. Scheunemann, Sungai Air Hidup, Edisi Kedua (Jakarta: BPK Gunung Mulia, 1965), 90. 90 .

${ }^{12}$ J. Oswald Sanders, Roh Kudus Penolong Kita (Jakarta: BPK Gunung Mulia, 1965), 5,6 .

${ }^{13}$ J. L. Ch. Abineno, Karunia-Karunia Roh Kudus (Jakarta: BPK Gunung Mulia, 1980),

${ }^{14}$ C. Peter Wagner, Manfaat Karunia Roh, cetakan kelima (Malang: Gandum Mas, 2005), 34 .
} 
Pertama, karunia-karunia Roh adalah suatu kecakapan khusus yang diberikan Allah dan disalurkan oleh Roh Kudus kepada orang-orang percaya untuk pengabdian Kristen. Kedua, karunia-karunia Roh bukan upah, tetapi pemberian sukarela yang dikerjakan oleh Roh Kudus sebagai alat perlengkapan untuk pelayanan baik secara internal maupun secara eksternal. Ketiga, karunia-karunia Roh diberikan menurut kemauan kedaulatan Roh Kudus, sesuai dengan kerelaan-Nya dan kedaulatan-Nya bagi orang percaya untuk membangun tubuh Kristus, satu dengan yang lain.

\section{Jenis Karunia-karunia Roh}

Pernyataan Paulus dalam 1 Korintus 12:4-6 sebagai berikut: "Ada rupa-rupa karunia, tetapi satu Roh. Dan ada rupa-rupa pelayanan, tetapi satu Tuhan. Dan ada berbagai-bagai perbuatan ajaib, tetapi Allah adalah satu yang mengerjakan semuanya dalam semua orang." Dalam 1 Korintus 12:14-16 kata Yunani charismatôn, diakoniôn, energêmatôn (karunia, diakonia, perbuatan ajaib) oleh Roh yang sama dalam mewujudkan kasih karunia untuk keuntungan umat pilihan yang tampaknya telah diabaikan. ${ }^{15}$

Dengan memerhatikan ayat-ayat tersebut di atas, nyatalah bahwa karunia-karunia Roh lebih dari satu dan untuk lebih meyakinkan jemaat Tuhan tentang kebenaran ini, Paulus memberikan suatu contoh yang sangat mudah untuk dipahami yakni tubuh manusia. Hal ini diungkapkan Rasul Paulus dalam 1 Korintus 12:12-27, yaitu tubuh terdiri dari berbagai-bagai anggota, antara lain: mata, telinga, mulut, tangan, kaki dan sebagainya, namun terikat dalam satu tubuh dan didayagunakan sesuai dengan fungsinya.

Melalui contoh yang diberikan oleh Rasul Paulus tersebut lebih membuka wawasan, sehingga kebenaran ini makin terang dan jelas, karena tidak hanya pada tempat tersebut saja Paulus menulis dan membahas tentang karunia-karunia Roh, tetapi juga di tempat-tempat yang lain (Rom. 12:6-8; Ef. 4:11, 12; 1 Kor. 7:7). Rasul Petrus juga menulis tentang karunia-karunia Roh sebagai berikut.

Layanilah seorang akan yang lain, sesuai dengan karunia yang telah diperoleh tiap-tiap orang sebagai pengurus yang baik dari kasih karunia Allah. Jika ada orang yang berbicara, baiklah ia berbicara sebagai orang yang menyampaikan firman Allah, jika ada orang yang melayani, baiklah ia melakukannya dengan kekuatan yang dianugerahkan Allah, supaya Allah

\footnotetext{
${ }^{15}$ Paul Elbert, "Calvin and The Spiritual Gifts," JETS 22, No. 3 (September 1979): 236.
} 
dimuliakan dalam segala sesuatu karena Yesus Kristus, Ialah yang empunya kemuliaan dan kuasa sampai selama-lamanya! Amin. ${ }^{16}$

Alkitab tidak memberikan batasan jumlah tentang karunia-karunia Roh, namun yang jelas bahwa karunia-karunia Roh lebih dari satu sebagaimana yang dituliskan oleh Alkitab dan yang akan diberikan kepada orang-orang percaya sesuai dengan kebutuhan pelayanan. Dalam kesempatan ini penulis akan mengklasifikasi karunia-karunia yang ditulis oleh Paulus dan Petrus dalam tiga bagian besar, yaitu:

Pertama, Karunia membangun diri sendiri (Personal Gowth). Karunia yang berhubungan dengan bagian ini adalah karunia bahasa Roh. Hal ini diungkapkan oleh Paulus dalam 1 Korintus 14:2a, 4a yakni, "Siapa yang berkata-kata dengan bahasa Roh, tidak berkata-kata kepada manusia, tetapi kepada Allah. Siapa yang berkata-kata dengan bahasa Roh, ia membangun dirinya sendiri." Dari pernyataan di atas, jelaslah bahwa orang yang berkarunia bahasa Roh tidak membangun jemaat tetapi membangun diri sendiri.

Kedua, Karunia membangun Sidang Jemaat (Internal Growth). Karunia-karunia yang dapat membangun sidang jemaat antara lain: nubuat, mengajar, menasihatkan, rasul, nabi, gembala, kesembuhan, melayani, memberi, memimpin, menunjukkan kemurahan, berkata-kata dengan hikmat, pengetahuan, iman, membedakan bermacam-macam roh, menafsirkan bahasa Roh, berbicara, kelajangan dan sebagainya. Hal ini secara jelas dikatakan oleh Rasul Paulus dalam Efesus 4:12, "untuk memperlengkapi orang-orang kudus bagi pekerjaan pelayanan, bagi pembangunan tubuh Kristus."

Ketiga, Karunia mengembangkan Sidang Jemaat (External Growth). Pengembangan sidang jemaat yang penulis maksudkan di sini adalah pelayanan yang diadakan di luar jemaat atau yang menjadi sasaran pelayanan adalah orang-orang yang belum menjadi anggota jemaat.

\section{Dasar Alkitab tentang Pendayagunaan Karunia-karunia Roh}

Karunia-karunia Roh adalah salah satu kebenaran yang tidak kalah pentingnya dengan kebenaran-kebenaran yang lain dalam Alkitab. Oleh karena itulah Allah melalui pekerjaan Roh Kudus menggerakkan para penulis Alkitab untuk memasukkan kebenaran tersebut ke dalam Alkitab. Alkitab yang terdiri dari Perjanjian Lama dan Perjanjian Baru, cukup banyak memuat serta menjelaskan kebenaran karunia-karunia Roh. Namun tidak sedikit orang meragukan kebenaran ini, padahal

\footnotetext{
${ }^{16}$ Lihat 1 Petrus 4:10, 1l. Ada karunia berbicara, melayani dengan tujuan untuk
} memuliakan Allah. 
kebenaran ini sangat penting, sebab karunia-karunia Roh adalah suatu pemberian Allah sebagai alat kelengkapan bagi pertumbuhan dan pengembangan jemaat lokal. Tanpa pendayagunaan karunia-karunia Roh dalam jemaat pasti jemaat tidak akan mengalami pertumbuhan, karena karunia-karunia Roh diberikan secara khusus untuk dipergunakan, didayagunakan, dimanfaatkan baik di dalam maupun di luar jemaat itu sendiri. Oleh karena itu, untuk lebih jauh dalam pembahasan mengenai karunia-karunia Roh, maka dalam bagian ini penulis memberikan dua dasar Alkitab tentang pendayagunaan karunia-karunia Roh yaitu:

Pertama, setiap anggota jemaat memiliki karunia-karunia Roh. Suatu hal yang tidak mungkin, apabila seseorang mau mendayagunakan karunianya sedangkan ia sendiri belum mengetahui bahkan meyakini bahwa ia memiliki suatu karunia. Hal ini diungkapkan oleh Paulus dalam 1 Korintus 12:11 (bdg. Rom. 12:3, 6; Ef. 4:7; 1 Pet. 4:10). Pernyataan Peniel Maiaweng mengatakan,

Bagi mereka yang telah percaya dan menerima Yesus sebagai Tuhan dan Juruselamat, baik pemuda maupun orang dewasa, Roh memeteraikan mereka menjadi anggota tubuh Kristus dan melengkapi mereka dengan karunia, yaitu kemampuan ilahi untuk melaksakan pelayanan yang sesuai dengan karunia yang mereka miliki (1 Kor. 12:12-30). ${ }^{17}$

Kedua, setiap anggota jemaat diberikan karunia-karunia Roh sebagai alat pelayanan. Kebenaran setiap anggota jemaat memiliki karunia Roh adalah suatu kebenaran yang pasti dan Alkitabiah. Hal ini dapat dilihat dalam 1 Korintus 12:12-31 di mana Paulus menganalogikan dengan tubuh, yakni terdiri dari banyak anggota dan berfungsi sesuai dengan penempatannya. Untuk lebih mengerti kebenaran ini, Yesus memberikan suatu perumpamaan yang terdapat dalam Injil Lukas 19:11-27, tentang "perumpamaan uang mina." Dari perumpamaan ini penulis mendapatkan suatu kekeliruan dari hamba-hamba yang telah dipercayakan untuk mengembangkan, melabakan uang mina tersebut. Namun di antara hamba-hamba itu ada yang mengerti dan ada pula yang tidak mengerti, sehingga tidak melaksanakan perintah tuannya. Ini menunjukkan bahwa narasi tersebut di atas dapat dijadikan pelajaran supaya anggota jemaat mengerti untuk apa karunia tersebut diberikan. Rick Warren dalam bukunya Pertumbuhan Gereja Masa Kini mengatakan, "Allah konsisten dengan rencana-Nya bagi kehidupan kita. Ia tidak akan memberikan kepada masing-masing kita bakat pembawaan sejak lahir, temperamen,

\footnotetext{
${ }^{17}$ Maiaweng, Pemberdayaan Jemaat Menjadi Pelayan Jemaat, 37.
} 
talenta, karunia rohani, dan pengalaman hidup dan kemudian tidak menggunakannya!"18

Demikian juga dengan karunia-karunia Roh yang dimiliki oleh setiap anggota jemaat adalah sebagai alat untuk melaksanakan pekerjaan pembangunan tubuh Kristus. Tanpa alat (karunia Roh) pembangunan tubuh Kristus akan mengalami hambatan bahkan tidak dapat dijalankan. Sebab, karunia-karunia Roh diberikan Allah Tritunggal kepada jemaatNya sebagai perlengkapan untuk didayagunakan demi mencapai hasil yang sebesar-besarnya.

\section{Definisi Pertumbuhan Jemaat}

Secara teologis, pertumbuhan gereja/jemaat mencakup semua komponen dari sebuah gereja/jemaat yang bertumbuh. Menurut Peter Wagner dalam bukunya yang berjudul Gereja Saudara Dapat Bertumbuh mengatakan, "Pertumbuhan Gereja berarti segala sesuatu yang mencakup soal membawa orang-orang yang tidak memiliki hubungan pribadi dengan Yesus Kristus ke dalam persekutuan dengan Dia dan membawa mereka menjadi anggota gereja yang bertanggung jawab."19 Definisi ini menekankan keseimbangan dalam pertumbuhan, yakni selain pertumbuhan kualitas juga pertumbuhan kuantitas. Ron Jensen dan Jim Stevens mengatakan dalam bukunya yang berjudul Dinamika Pertumbuhan Gereja sebagai berikut: "Pertumbuhan Gereja adalah kenaikan yang seimbang dalam kualitas, kuantitas, dan kompleksitas organisasi sebuah gereja lokal." ${ }^{20}$

Berdasarkan penjelasan di atas, maka dapat disimpulkan bahwa pertumbuhan jemaat adalah suatu perkembangan, kemajuan, pertambahan jemaat, baik secara kualitas menyangkut pengenalan secara pribadi terhadap Yesus Kristus yang makin mendalam dan secara kuantitas menyangkut pertambahan jumlah bilangan orang yang menjadi percaya.

\section{Dampak Pendayagunaan Karunia-Karunia Roh dalam Pertumbuhan Jemaat}

Pertumbuhan jemaat adalah dambaan dan harapan Yesus Kristus sebagai Kepala gereja bagi gereja-Nya. Artinya tidak ada alasan untuk

\footnotetext{
${ }^{18}$ Warren, Pertumbuhan Gereja Masa Kini, 378.

${ }^{19}$ C. Peter Wagner, Gereja Saudara Dapat Bertumbuh (Malang: Gandum Mas, 1990), 11

${ }^{20}$ Ron Jenson dan Jim Stevens, Dinamika Pertumbuhan Gereja (Malang: Gandum Mas, 1996), 8.
} 
gereja tidak bertumbuh. Hal ini sangat jelas melalui pernyataan Yesus dalam Matius 28:18-20, sebagai berikut:

Yesus mendekati mereka dan berkata: Kepada-Ku telah diberikan segala kuasa di sorga dan di bumi. Karena itu pergilah, jadikanlah semua bangsa murid-Ku dan baptislah mereka dalam nama Bapa dan Anak dan Roh Kudus, dan ajarlah mereka melakukan segala sesuatu yang telah Kuperintahkan kepadamu. Dan ketahuilah, Aku menyertai kamu senantiasa sampai akhir zaman.

Dari pernyataan kebenaran firman Allah ini jelas sekali bahwa Yesus sangat menghendaki agar gereja/jemaat harus bertumbuh. Alasannya sangat jelas, "Ia menghendaki supaya jangan ada yang binasa, melainkan supaya semua orang berbalik dan bertobat" (2 Ptr. 3:9). Peter Wagner mengungkapkan, "Allah menghendaki agar semua orang diselamatkan dari dosa dan kematian kekal. Allah adalah kasih dan Ia menginginkan agar tiap-tiap orang diperdamaikan kepada-Nya. Karena alasan itulah Ia mengutus Anak-Nya yang tunggal, Yesus Kristus."2l

Dengan memerhatikan penjelasan di atas, maka jelaslah bahwa Allah konsisten dengan pertumbuhan gereja/jemaat. Untuk mewujudkan pertumbuhan jemaat-Nya, maka Allah memberikan karunia-karunia Roh bagi setiap orang percaya supaya didayagunakan dalam pelayanan bagi pertumbuhan jemaat itu sendiri.

Penulis sangat yakin bahwa apabila karunia-karunia Roh yang dimiliki oleh setiap anggota jemaat didayagunakan dalam pelayanan, maka akan berdampak dalam pertumbuhan jemaat, baik secara kualitas maupun kuantitas.

\section{Pertumbuhan Kualitas}

Alkitab mengatakan dalam 1 Korintus 12:7, "Tetapi tiap-tiap orang dikaruniakan penyataan Roh untuk kepentingan bersama." Dan dalam 1 Korintus 14:12, "Demikian pula dengan kamu. Kamu memang berusaha untuk memperoleh karunia-karunia Roh, tetapi lebih dari pada itu hendaklah kamu berusaha mempergunakannya untuk membangun jemaat." Berdasarkan pernyataan ayat-ayat di atas menyatakan bahwa apabila karunia-karunia Roh didayagunakan oleh setiap orang percaya, maka berdampak dalam pertumbuhan secara kualitas, yaitu jemaat terbangun secara pribadi. Dalam Kisah Para Rasul 2:42-47 menjelaskan bahwa orang-orang percaya yang sedang bertumbuh secara kualitas dalam hubungan dengan Kristus dan orang-orang percaya. Pertumbuhan kualitatif terlihat dalam perubahan tingkah laku dan karakter. Gereja mula-mula bertumbuh secara kualitatif karena mereka bertekun dalam

\footnotetext{
${ }^{21}$ C. Peter Wagner, Strategi Perkembangan Gereja (Malang: Gandum Mas, 1996), 28.
} 
pengajaran rasul-rasul, dalam persekutuan, dalam doa, dan dalam ibadah bersama (ayat 42, 47).

Christian A. Schwarz dalam bukunya yang berjudul Pertumbuhan Gereja yang Alamiah, menemukan delapan karakteristik kualitas dari gereja yang bertumbuh, salah satunya adalah pelayanan yang berorientasi pada karunia. ${ }^{22}$ Selanjutnya, dalam sebuah penelitian yang dilakukan oleh Peter Wagner dengan ratusan gembala jemaat, ia berhasil menyusun sebuah daftar tentang dua belas faktor kualitas yang dapat diukur dalam kehidupan sebuah jemaat menurut aturan tingkatannya, pada bagian kelima ia mengatakan, pelayanan kaum awam. Kaum awam di gereja ikut terlibat dalam berbagai macam pelayanan, seperti pengajaran dan pemuridan. Keterlibatan kaum awam itu mungkin terjadi ketika mereka secara sadar menemukan, mengembangkan, dan menggunakan karuniakarunia rohani mereka. ${ }^{23}$

Berdasarkan penjelasan di atas, maka dapat disimpulkan bahwa dengan mendayagunakan karunia-karunia Roh dalam pelayanan berdampak dalam pertumbuhan jemaat secara kualitas.

\section{Pertumbuhan Kuantitas}

Pertumbuhan kuantitas atau pertumbuhan jumlah sering disebut dalam kitab Kisah Para Rasul. Maksudnya, kitab Kisah Para Rasul melalui Lukas mencatat tentang pertumbuhan jemaat secara kuantitas. Kebenaran pertumbuhan jemaat secara kuantitas terlihat dengan jelas di dalam beberapa pernyataan firman Tuhan berikut ini, "orang-orang yang menerima perkataannya itu memberi diri dibaptis dan pada hari itu jumlah mereka bertambah kira-kira tiga ribu jiwa" (Kis. 2:4l; bdg. Kis. 2:47; 4:4; 5:14; 9:31; 21:20).

Hal ini menunjukkan bahwa pertumbuhan secara kuantitas sangat diharapkan Tuhan bagi gerejanya. Itu sebabnya, karunia-karunia Roh diberikan Allah kepada jemaatnya bukan hanya untuk pertumbuhan secara kualitas, tetapi juga untuk pertumbuhan secara kuantitas. Kebenaran ini sangat jelas, seperti penulis sudah jelaskan pada bagian terdahulu, yakni kepentingan pendayagunaan karunia-karunia Roh yaitu pertumbuhan secara kuantitas.

Penulis yakin apabila karunia-karunia Roh dalam setiap anggota jemaat didayagunakan dengan sesungguhnya, maka akan berdampak dalam pertumbuhan jemaat secara kuantitas. Alasannya, ada beberapa karunia Roh, misalnya mukjizat, kesembuhan, berkata-kata dengan hikmat, penginjilan, misionaris dan sebagainya. Jika didayagunakan akan

${ }^{22}$ Christian A. Schwarz, Pertumbuhan Gereja yang Alamiah (Jakarta: Metanoia Publishing, 1999), 11-20.

${ }^{23}$ C. Peter Wagner, Memimpin Gereja Anda Agar Bertumbuh (Jakarta: Harvest Publishing House, 1995), 26-27. 
mendatangkan pertumbuhan secara kuantitas. Hal ini terlihat jelas dalam pertumbuhan jemaat mula-mula, di mana pelayanan para rasul diwarnai dengan mukjizat-mukjizat dan kesembuhan, sehingga banyak orang yang menjadi percaya kepada Tuhan Yesus.

\section{Pembahasan dan Analisis Hasil Penelitian}

Sebaran sampel terdiri atas 100 responden jemaat GPdI El-Shaddai Makassar. Penelitian secara kualitatif dengan sebaran angket pada responden yang terdiri dari laki-laki $41 \%$ dan perempuan $59 \%$. Responden yang sudah menikah 65\% dan 35\% belum menikah. Sebaran responden dengan profesi sebagai pendeta 2\%; 5\% sebagai pengerja (keluaran Sekolah Alkitab yang sedang berpraktik), 10\% sebagai majelis yang membawahi 10 bidang pelayanan dan $83 \%$ sebagai pelayan dalam berbagai bidang pelayanan.

\section{Pemahaman tentang Karunia-karunia Roh}

Hasil dari pertanyaan angket pertama adalah sebagai berikut. Pertanyaan pertama, "Apakah Anda sudah pernah mendengar melalui khotbah, ceramah, pendalam Alkitab tentang karunia-karunia Roh?" Berdasarkan hasil penelitian menyatakan bahwa $98 \%$ pelayan-pelayan dalam jemaat GPdI El-Shaddai telah mendengar khotbah, ceramah, pendalaman Alkitab. Hal ini telah dilakukan oleh gembala melalui khotbah seri dan juga melalui interaksi langsung dengan PELWAP (Pelayanan Wanita Pantekosta) dan PELPRIP (Pelayanan Pria Pantekosta) serta PELPRAP (Pelayanan Pemuda dan Remaja Pantekosta).

Pertanyaan kedua, "Apakah Anda sudah mengerti/mengenal karunia-karunia Roh setelah mendengar khotbah, ceramah, pendalam Alkitab dan membaca buku?" Hasilnya menyatakan bahwa 86\% pelayan-pelayan dalam jemaat GPdI El-Shaddai memahami tentang karunia-karunia Roh karena mereka telah mendengar khotbah dan interaksi langsung dengan gembala. Adapun yang menjawab kadangkadang memahami tentang karunia-karunia Roh ketika dikhotbahkan karena tidak beribadah pada saat khotbah disampaikan dan dapat juga karena tidak konsentrasi pada saat khotbah disampaikan.

Pertanyaan ketiga, "Apakah Anda pernah berdoa kepada Tuhan untuk menemukan karunia Roh dalam diri Anda?" Hasilnya menyatakan bahwa $87 \%$ jemaat pernah berdoa kepada Tuhan untuk menemukan karunia Roh dalam diri mereka. Namun demikian masih ada yang kadang-kadang berdoa kepada Tuhan untuk menemukan karunia Roh dalam diri mereka sebanyak $9 \%$, dan ada $4 \%$ yang tidak pernah berdoa untuk menemukan karunia Roh dalam diri mereka. Responden 
menjawab lebih banyak pernah berdoa, karena salah satu cara menemukan karunia Roh yang dikhotbahkan adalah melalui berdoa. Alasan yang lain karena mereka memahami betapa pentingnya apabila pelayan-pelayan menemukan karunia Roh akan lebih efektif dalam pelayanan.

Dengan memerhatikan pertanyaan keempat, "Apakah Anda percaya bahwa karunia-karunia Roh dapat ditemukan melalui doa?" Hasilnya menyatakan bahwa 94\% pelayan yang ada di jemaat GPdI El-Shaddai yang menjadi responden percaya bahwa karunia-karunia Roh dapat ditemukan melalui doa, sedangkan $4 \%$ menjawab kadang-kadang dan $2 \%$ yang sama sekali tidak percaya. Melalui jawaban responden di atas menyatakan bahwa mereka percaya karunia-karunia Roh dapat ditemukan melalui doa. Hal ini sesuai dengan firman Allah dalam Injil Lukas 11:9-13, mengatakan, “... Mintalah, maka akan diberikan kepadamu; carilah, maka kamu akan mendapat; ketoklah, maka pintu akan dibukakan bagimu."

\section{Keterlibatan dalam Pelayanan}

Pertanyaan kelima, "Apakah anda terlibat dalam pelayanan di gereja?" Hasilnya menyatakan bahwa bahwa $82 \%$ pelayan yang ada di jemaat GPdI El-Shaddai yang terlibat dalam berbagai bidang pelayanan di jemaat GPdI El-Shaddai Makassar, sedangkan 18\% kadang-kadang terlibat dalam pelayanan. Artinya semua responden terlibat dalam pelayanan.

Pertanyaan yang lain menyatakan bahwa $80 \%$ pelayan yang ada di jemaat GPdI El-Shaddai yang terlibat secara aktif dalam berbagai bidang pelayanan di jemaat GPdI El-Shaddai Makassar, sedangkan 17\% kadangkadang terlibat dalam berbagai bidang pelayanan, dan 3\% tidak terlibat aktif dalam berbagai bidang pelayanan. Keterlibatan responden secara aktif dalam berbagai bidang pelayanan sangat menonjol, misalnya sebagai guru sekolah minggu, sebagai pemain rebana, sebagai singers, sebagai pemain musik dan sebagai pelayan di sektor-sektor, persekutuan/unit doa dan sebagainya. Bahkan ada beberapa orang yang sama terlibat aktif dalam beberapa bidang pelayanan. Ini menunjukkan secara jelas tentang keaktifan pelayan-pelayan di jemaat GPdI ElShaddai Makassar sekalipun belum seratus persen. Hasil dari pertanyaan yang diajukan menunjukkan bahwa $72 \%$ pelayan yang ada di jemaat GPdI El-Shaddai yang terlibat dalam berbagai bidang pelayanan di jemaat GPdI El-Shaddai Makassar mengalami kemajuan, sedangkan 24\% kadang-kadang mengalami kemajuan, dan 4\% tidak mengalami kemajuan dalam pelayanan. Menurut pengamatan penulis secara langsung bahwa salah satu penyebabnya adalah para pelayan sebagian besar mahasiswa dan pekerja/karyawan, maka kesempatan sangat 
terbatas, sehingga tidak maksimal di dalam pelayanan dan sudah pasti akan berdampak pada hasil dari pelayanan itu sendiri.

Hasil pertanyaan angket yang lain menyatakan bahwa 64\% tidak mengalami kegagalan/kemunduran dalam pelayanan, dan terdapat 35\% yang kadang-kadang mengalami kemunduran dalam pelayanan. Menurut penulis penyebab kadang-kadang mengalami kegagalan/kemunduran, oleh karena jenis pelayanan yang dijalankan tidak sesuai dengan karunia yang dimiliki dan juga kesibukan sebagai mahasiswa dan karyawan sehingga terlalu sedikit waktu dan kadang-kadang tidak punya waktu lagi dalam persekutuan secara pribadi dengan Tuhan dalam doa.

Hasil pertanyaan lain menyatakan $94 \%$ pelayan yang ada di jemaat GPdI El-Shaddai mengalami rasa senang/sukacita dengan pelayanan yang sedang dijalankan, sedangkan $4 \%$ kadang-kadang mengalami senang/sukacita dalam pelayanan yang sedang dijalankan, dan 2\% yang tidak merasa senang/sukacita dalam pelayanan sekarang ini. Menurut penulis hasil ini sangat baik dan harus dipertahankan dengan memberikan motivasi-motivasi kepada pelayan-pelayan sehingga mereka tetap bersukacita dalam menjalankan pelayanan. Sebab seberat apapun suatu pelayanan apabila disertai dengan sukacita maka menjadi berkat bagi orang lain.

Hasil angket mengenai kejenuhan dalam melayani menunjukkan bahwa hanya 3\% responden yang mengalami kejenuhan dalam melayani, sementara terdapat $82 \%$ yang tidak mengalami kejenuhan. Bila dibandingkan dengan data 94\% yang mengalami sukacita dalam pelayanan berarti setiap pelayanan terdapat masa kejenuhan, namun dapat di atasi dengan mengadakan penyegaran rohani atau retret pekerja, dan kegiatan-kegiatan yang lainnya yang lebih kreatif dan menggairahkan supaya semangat melayani Tuhan kembali dikuatkan dan mengalami sukacita.

Hasil pertanyaan berikutnya menunjukkan bahwa 69\% pelayan yang ada di jemaat GPdI El-Shaddai menjawab percaya bahwa melalui penumpangan tangan salah satu cara untuk menemukan karunia Roh, sedangkan $17 \%$ menjawab kadang-kadang percaya, dan 14\% tidak percaya bahwa melalui penumpangan tangan dapat menemukan karunia Roh. Walaupun yang menjawab masih jauh lebih banyak daripada yang kadang-kadang dan tidak percaya bahwa melalui penumpangan tangan seseorang dapat menemukan karunia Roh. Alkitab menyatakan bahwa Musa melakukan penumpangan tangan kepada Yosua dalam Perjanjian Lama untuk membawa bangsa Israel memasuki tanah Kanaan. Selanjutnya ada $27 \%$ pelayan di jemaat GPdI El-Shaddai yang menjawab bahwa melalui penumpangan tangan mereka menemukan karunia Roh, sedangkan 13\% menjawab kadang-kadang melalui penumpangan tangan, dan $60 \%$ tidak melalui penumpangan tangan mereka menemukan 
karunia Roh. Hal ini berarti jemaat telah memahami bahwa penumpangan tangan untuk memperoleh karunia Roh hanyalah salah satu cara dari sekian cara yang Allah dapat buat bagi seseorang untuk mendapatkan karunia Roh.

\section{Pendayagunaan Karunia-karunia Roh}

Pertanyaan berikut menjelaskan bahwa $57 \%$ pelayan yang ada di jemaat GPdI El-Shaddai yang menjadi sampel dalam karya ilmiah ini menjawab bahwa mereka melayani di organisasi yang memberi kesempatan untuk pelayanan karunia Roh, 7\% menjawab kadangkadang dan 36\% menjawab mereka melayani di organisasi yang tidak memberikan kesempatan untuk pelayanan karunia Roh. Sekalipun secara umum karunia-karunia Roh belum ditemukan sebagaimana diharapkan, namun organisasi di mana mereka turut terlibat dalam pelayanan memberikan kesempatan untuk pelayanan karunia Roh. Ini berarti peluang untuk penerapan pendayagunaan karunia Roh dalam pelayanan melalui organisasi. Adapun yang menjawab organisasi gereja tidak memberi kesempatan untuk pelayanan karunia Roh oleh karena tidak semua bidang pelayanan dapat dilayani oleh semua pelayan, misalnya: pelayanan perjamuan kudus hanya untuk para majelis jemaat.

Organisasi di mana responden melayani belum mengatur pelayanan sesuai dengan karunia yang dimiliki, namun secara manual pengaturan pelayanan bagi responden sudah teratur. Oleh karena itulah apabila setiap pelayan telah menemukan karunianya, maka organisasi akan mengaturnya sesuai dengan karunia masing-masing supaya semua pelayan dalam jemaat GPdI El-Shaddai Makassar berfungsi sesuai dengan karunianya masing-masing. Secara manual pelayan-pelayan dalam jemaat ini telah mendapat bimbingan dan pengarahan dalam pelayanan, misalnya: bagaimana mengajar sekolah minggu dengan efektif, bagaimana berkhotbah secara praktis, bagaimana memenangkan jiwa melalui penginjilan pribadi, dan sebagainya. Namun belum mendapat bimbingan secara khusus tentang karunia yang dimiliki secara pribadi, tetapi akan dilaksanakan kemudian sesuai dengan urutan dalam strategi pendayagunaan karunia-karunia Roh.

Faktor pendukung pendayagunaan karunia-karunia Roh menunjukkan bahwa 54\% pelayan yang ada di jemaat GPdI El-Shaddai menjawab bahwa fasilitas dalam jemaat turut menunjang karunia yang dimiliki, sedangkan yang menjawab kadang-kadang 9\%, dan yang menjawab tidak/belum 37\%. Dengan sendirinya apabila karunia-karunia Roh telah ditemukan oleh responden, maka fasilitas dalam jemaat akan turut dilengkapi sesuai dengan karunia masing-masing demi untuk mempermudah di dalam pelaksanaan karunia itu sendiri. Sebab fasilitas 
dalam jemaat merupakan sarana dalam menunjang dalam pelaksanaan karunia-karunia Roh.

Dampak karunia yang dimiliki bagi pertumbuhan jemaat secara kualitas menunjukkan bahwa 38\% pelayan yang ada di jemaat GPdI El Shaddai yang menjadi sampel dalam karya ilmiah ini menjawab bahwa pelayanan dengan karunia yang dimiliki berdampak terhadap pertumbuhan jemaat secara kualitas, sedangkan yang menjawab kadangkadang 29\%, dan yang menjawab tidak/belum 33\%. Menurut penulis wajar apabila jawaban responden belum maksimal tentang dampak terhadap pertumbuhan jemaat secara kualitas melalui pelayanan karunia-karunia Roh, sebab hal ini belum dilaksanakan sesuai dengan yang diharapkan. Namun apabila responden telah menemukan karunia mereka masing-masing dan didayagunakan dengan sebaik-baiknya sesuai dengan karunianya, maka terjadi suatu pertumbuhan secara kualitas dalam jemaat itu sendiri.

Selanjutnya dampak karunia-karunia Roh untuk pertumbuhan jemaat secara kuantitas menunjukkan bahwa $41 \%$ pelayan yang ada di jemaat GPdI El-Shaddai menjawab bahwa pelayanan dengan karunia yang dimiliki tidak berdampak terhadap pertumbuhan jemaat secara kuantitas, sedangkan yang menjawab kadang-kadang 29\%, dan yang menjawab ya sebanyak 30\%. Pertumbuhan jemaat secara kuantitas akan menjadi maksimal apabila karunia-karunia Roh yang dimiliki oleh jemaat didayagunakan dengan benar. Namun menurut penulis wajar apabila jawaban responden belum maksimal tentang dampak terhadap pertumbuhan jemaat secara kuantitas melalui pelayanan karuniakarunia Roh, sebab hal ini belum dilaksanakan sesuai dengan yang diharapkan.

\section{Kesimpulan Analisis Angket Pertama}

Penulis memberikan beberapa kesimpulan sehubungan dengan pendayagunaan karunia-karunia Roh terhadap pertumbuhan jemaat di GPdI El-Shaddai Makassar sebagai berikut:

Pertama, secara keseluruhan pelayan-pelayan jemaat GPdI Elshaddai sudah pernah mendengar melalui khotbah, ceramah dan pendalaman Alkitab, namun demikian belum semua pelayan-pelayan memahami dengan benar, tetapi pada umumnya sudah memahami dan mengerti.

Kedua, keterlibatan dan keaktifan pelayan-pelayan jemaat dalam berbagai bidang pelayanan cukup signifikan. Hal ini disebabkan karena organisasi di mana mereka melayani memberikan kesempatan pelayanan.

Ketiga, sekalipun pelayan-pelayan sangat aktif dalam pelayanan, ternyata mereka belum mengenal karunia yang dimilikinya, sehingga 
mereka belum diarahkan dan dilatih sesuai dengan karunia mereka masing-masing, apalagi diposisikan sesuai dengan karunianya.

Keempat, itulah sebabnya pertumbuhan secara kualitas dan kuantitas masih sangat terbatas, sekalipun tidak dapat disangkal bahwa di jemaat GPdI El-Shaddai terjadi suatu pertumbuhan. Namun, apabila semua jemaat telah menemukan karunianya dan berfungsi sesuai dengan karunianya, maka pertumbuhan dalam jemaat GPdI El-Shaddai akan lebih meningkat.

\section{Pengelompokan Karunia-karunia Roh}

Bagian ini membahas hasil analisis angket kedua, dengan menggunakan langkah kedua dari tabel Houts yang dimodifikasi oleh Wagner. ${ }^{24}$

Untuk penilaiannya penulis hanya mengambil empat hasil yang terbanyak atau teratas, kemudian mengelompokkannya dalam empat kelompok, yakni: kelompok 1, kelompok 2, kelompok 3, dan kelompok 4 sesuai dengan skor/nilai tertinggi, sebagai berikut:

Tabel 1. Hasil Inventarisasi Karunia

\begin{tabular}{|c|c|c|c|c|c|c|}
\hline No & Karunia-Karunia & $\underset{1}{\text { Kelompok }}$ & $\begin{array}{c}\text { Kelompok } \\
2\end{array}$ & $\begin{array}{c}\text { Kelompok } \\
3\end{array}$ & $\begin{array}{l}\text { Kelompok } \\
4\end{array}$ & Jumlah \\
\hline 1 & Nubuat & 0 & 1 & 1 & 0 & 2 \\
\hline 2 & Gembala & 2 & 7 & 2 & 2 & 13 \\
\hline 3 & Mengajar & 7 & 7 & 6 & 0 & 20 \\
\hline 4 & Hikmat & 9 & 14 & 12 & 2 & 37 \\
\hline 5 & Pengetahuan & 10 & 1 & 1 & 0 & 12 \\
\hline 6 & Memberi nasihat & 11 & 25 & 10 & 1 & 47 \\
\hline 7 & $\begin{array}{l}\text { Membedakan } \\
\text { bermacam-macam roh }\end{array}$ & 1 & 0 & 0 & 0 & 1 \\
\hline 8 & Membagi-bagikan & 13 & 20 & 8 & 0 & 41 \\
\hline 9 & Pertolongan & 12 & 12 & 7 & 0 & 31 \\
\hline 10 & Kemurahan & 3 & 6 & 8 & 1 & 18 \\
\hline 11 & Misionaris & 6 & 8 & 2 & 0 & 16 \\
\hline 12 & Pemberita Injil & 3 & 4 & 1 & 0 & 8 \\
\hline 13 & Memberi Tumpangan & 24 & 17 & 5 & 0 & 46 \\
\hline 14 & Iman & 1 & 4 & 1 & 0 & 6 \\
\hline 15 & Kepemimpinan & 0 & 2 & 3 & 0 & 5 \\
\hline 16 & Kepengurusan & 6 & 5 & 2 & 0 & 13 \\
\hline 17 & Mukjizat & 0 & 0 & 0 & 0 & 0 \\
\hline 18 & Penyembuhan & 0 & 1 & 0 & 0 & 1 \\
\hline 19 & Bahasa Roh & 4 & 5 & 0 & 0 & 9 \\
\hline 20 & $\begin{array}{l}\text { Menafisrkan Bahasa } \\
\text { Roh }\end{array}$ & 0 & 0 & 0 & 0 & 0 \\
\hline 21 & $\begin{array}{l}\text { Hidup Miskin secara } \\
\text { Sukarela }\end{array}$ & 9 & 4 & 3 & 1 & 17 \\
\hline 22 & Hidup Lajang & 0 & 1 & 0 & 0 & 1 \\
\hline 23 & Doa Syafaat & 4 & 4 & 2 & 0 & 10 \\
\hline 24 & Pelepasan & 1 & 0 & 0 & 0 & 1 \\
\hline \multirow[t]{2}{*}{26} & Pelayanan & 29 & 14 & 1 & 1 & 45 \\
\hline & Jumlah & 155 & 162 & 75 & 8 & 400 \\
\hline
\end{tabular}

${ }^{24}$ Wagner, Manfaat Karunia Roh, 293. 
Tabel di atas menunjukkan hasil inventarisasi karunia-karunia Roh dari pelayan-pelayan di jemaat GPdI El-Shaddai Makassar dengan penjelasan sebagai berikut:

Pertama, semua responden telah mengisi dan mengembalikan angket inventarisasi karunia atau dapat dikatakan $100 \%$.

Kedua, semua jawaban responden telah dianalisis berdasarkan skor/nilai tertinggi dan kemudian dikelompokkan menjadi empat kelompok sesuai dengan karunianya. Semua nilai yang tertinggi dikelompokkan pada kelompok pertama, kedua tertinggi pada kelompok dua, ketiga tertinggi pada kelompok tiga, dan keempat tertinggi pada kelompok empat.

Ketiga, semua jawaban responden yang sama pada satu karunia dikelompokkan sesuai dengan nilainya kemudian dijumlahkan. Misalnya, karunia pelayanan, kelompok pertama 29 orang, kedua 14, ketiga 1 orang, dan keempat 1 orang, sehingga berjumlah 45 orang.

Keempat, setelah memerhatikan jawaban dari responden, ternyata karunia yang dominan bagi pelayan-pelayan di GPdI El-Shaddai dapat diurutkan sebagai berikut: karunia nasihat 47 orang, karunia memberi tumpangan 46 orang, karunia pelayanan 45 orang, karunia membagi-bagi 41 orang, karunia hikmat 37 orang, karunia pertolongan 31 orang, karunia mengajar 20 orang, karunia kemurahan 18 orang, karunia hidup miskin dengan sukarela 17 orang, karunia misionaris 16 orang, karunia gembala 13 orang, karunia kepengurusan 13 orang, karunia pengetahuan 12 orang, karunia doa syafaat 10 orang, karunia bahasa roh 9 orang, karunia pemberita injil 8 orang, karunia iman 6 orang, karunia kepemimpinan 5 orang, karunia nubuat 2 orang, karunia membedakan bermacam-macam roh 1 orang, karunia pemyembuhan 1 orang, karunia hidup lajang 1 orang, karunia pelepasan 1 orang, karunia mujizat 0 orang, karunia menafsirkan bahasa Roh tidak ada.

Kelima, sebagaimana telah dijelaskan sebelumnya bahwa penggunaan inventarisasi karunia melalui angket/kuesioner Houts yang dimodifikasi oleh Wagner selain telah memberkati banyak orang, namun menurut Wagner, hasil tes itu jangan dianggap sebagai bersifat menentukan. ${ }^{25}$ Artinya cara ini bukan segala-galanya, tetapi hanyalah merupakan salah satu cara atau titik tolak untuk dapat menemukan karunia Roh. Itu sebabnya penulis sangat yakin bahwa pasti terdapat banyak kekurangan dan kesalahan, misalnya responden menjawab pertanyaan dengan tidak sungguh-sungguh, sehingga menghasilkan jawaban yang kurang tepat. Namun demikian cara ini sangat membantu dalam menemukan karunia-karunia Roh yang belum terungkap.

\footnotetext{
${ }^{25}$ Ibid, 272.
} 


\section{Kesimpulan Analisis Angket Kedua}

Setelah menganalisis dan menginterpretasi data pada tabel angket kedua, maka selanjutnya penulis memberikan beberapa kesimpulan sehubungan dengan pendayagunaan karunia Roh terhadap pertumbuhan jemaat di GPdI El-Shaddai Makassar sebagai berikut:

Pertama, dengan memerhatikan jawaban responden di atas menyatakan bahwa sebagian responden telah menjawab dengan sungguh-sungguh, sehingga melalui pengamatan langsung penulis bahwa karunia yang dimiliki sesuai dengan perilaku responden di lapangan pelayanan. Namun sebagian responden tidak menjawab dengan sungguh-sungguh sehingga jawabannya tidak menyatakan perilaku responden di lapangan pelayanan.

Kedua, dengan memerhatikan jawaban responden di atas, khususnya empat karunia yang sangat dominan, yakni karunia nasihat, karunia memberi tumpangan, karunia pelayanan dan karunia membagibagi yang dimiliki oleh pelayan-pelayan di GPdI El-Shaddai Makassar, maka hal ini menurut penulis kemungkinan dipengaruhi oleh dua faktor, yakni:

Pertama adalah kepercayaan terhadap pengajaran firman Allah yang telah dipercayai, misalnya: memberi tumpangan, saling menasihati, memberi lebih mulia daripada menerima, dan sebagainya sehingga membuat karunia-karunia tersebut lebih dominan dari yang lainnya.

Kedua adalah budaya, di mana jemaat GPdI El-Shaddai pada umumnya dari suku Toraja yang sangat kental dengan kekeluargaan sehingga praktik saling membantu dan menolong sangat menonjol.

Dengan hasil inventarisasi karunia ini, maka jelas semua responden telah menemukan karunia mereka masing-masing, sehingga dengan demikian akan dikelompokkan dan seterusnya dibina, dilatih dan kemudian didelegasikan dalam pelayanan sesuai dengan karunia masingmasing.

Pendayagunaan karunia-karunia roh berpengaruh juga secara kuantitas terhadap pertumbuhan jemaat yaitu sejak tahun 1979 dengan jumlah anggota 22 jiwa dan data 29 Februari 2012, jumlah anggota jemaat 1080 jiwa. $^{26}$ Ini berarti selama tiga puluh tiga tahun mengalami pertumbuhan 1058 jiwa atau pertambahan rata-rata 32.06 jiwa pertahun.

\section{Kesimpulan}

Pertama, karunia-karunia Roh adalah salah satu dari sekian kebenaran yang terdapat dalam Alkitab dan bersumber dari Allah

${ }^{26}$ Data statistik jumlah jemaat GPdI El-Shaddai sejak tahun 1979 hingga 29 Februari 2012, Makassar. 
Tritunggal yang bersifat ilahi dan adikodrati, serta terdiri dari banyak jenis yang dapat diklasifikasikan menurut fungsinya dalam tiga bagian besar, yakni: untuk membangun diri sendiri, untuk membangun jemaat dan untuk pelayanan di luar jemaat.

Kedua, Alkitab secara jelas menyatakan bahwa setiap anggota jemaat yang telah dilahirkan kembali, memiliki karunia Roh dan karunia Roh yang dimiliki digunakan sebagai alat pelayanan bagi pembangunan tubuh Kristus.

Ketiga, karunia-karunia Roh yang dimiliki oleh setiap anggota jemaat mempunyai dua kepentingan, yakni: kepentingan internal yaitu untuk kepentingan bersama, untuk memperkuat persatuan jemaat, untuk memperlengkapi orang-orang kudus bagi pelayanan, dan kepentingan eksternal yaitu untuk meluaskan kesaksian dan pelayanan jemaat serta untuk membantu dalam penginjilan.

Keempat, di dalam mendayagunakan karunia-karunia Roh yang dimiliki oleh setiap anggota jemaat, diperlukan suatu strategi. Adapun strategi yang digunakan dalam mendayagunakan karunia-karunia Roh adalah memperkenalkan karunia-karunia Roh melalui khotbah, ceramah, pendalaman Alkitab, sehingga mereka meyakini dan memercayai bahkan dapat menemukan karunianya, kemudian dikelompokkkan dalam satu kelompok semua yang memiliki karunia sejenis, dibina, dilatih dan akhirnya ditempatkan pada pelayanan yang sesuai dengan karunianya.

Kelima, untuk lancarnya pelaksanaan strategi yang telah dibuat, maka diperlukan penunjang untuk memudahkan pelaksanaannya. Adapun faktor-faktor penunjang tersebut adalah organisasi yang mantap, menerapkan bimbingan dalam jemaat, dalam hal ini karuniakarunia Roh, serta adanya fasilitas yang menunjang berupa: keuangan, alat-alat dan lapangan pelayanan yang tersedia.

Keenam, dengan pendayagunaan karunia-karunia Roh yang dimiliki oleh setiap jemaat dalam berbagai lapangan pelayanan, maka terjadi suatu pertumbuhan, baik secara kualitas maupun kuantitas.

\section{Kepustakaan}

Abineno, J. L. Ch. Karunia-Karunia Roh Kudus. Jakarta: BPK Gunung Mulia, 1980.

Aland, Kurt. eds. et al. The Greek New Testament Dictionary. West Germany: Biblia-Druck Gmbh Stuttgart, 1983.

Christy, Mark W. "Spiritual Gifts and Church Growth." Southwestern Baptist Theological Seminary, 2009. Diakses 25 Januari 2015. http://storage.cloversites.com/midcitiescommunitychurch/documen ts/SPIRITUAL\%20GIFTS\%20AND\%20CHURCH\%20GROWTH_ 2.pdf. 
Elbert, Paul. "Calvin and The Spiritual Gifts." JETS 22, no. 3 (September 1979): 235-256.

Hodges, Melvin L. dan Ralph D. Williams. Sidang Jemaat Yang Berkembang. Malang: Gandum Mas, 1962.

Jenson, Ron dan Jim Stevens. Dinamika Pertumbuhan Gereja. Malang: Gandum Mas, 1996.

Kindsay, Gordon. Segala Sesuatu Tentang Karunia-karunia Rohul Kudus, Cetakan ketiga. Jakarta: YPII, 1982.

Lang, J. Stephen. 1001 Hal yang Ingin Anda Ketahui tentang Roh Kudus, Cetakan pertama. Jakarta : YPI Imanuel, 2002.

Maiaweng, Peniel. Pemberdayaan Jemaat Menjadi Pelayan Jemaat. Tenggarong: STT Tenggarong, 2004.

Sanders, J. Oswald. Roh Kudus Penolong Kita. Jakarta: BPK Gunung Mulia, 1965, 90.

Scheunemann, D. Sungai Air Hidup, Edisi kedua. Jakarta: BPK Gunung Mulia, 1965.

Stott, John, R. W. Baptisan dan Kepenuhan. Jakarta: BPK Gunung Mulia, 1984.

Schwarz, Christian A. Pertumbuhan Gereja yang Alamiah. Jakarta: Metanoia Publishing, 1999.

Tomatala, Yakob. Penatalayanan Gereja yang Efektif di Dunia Modern, Cetakan pertama. Malang: Gandum Mas, 1987.

Vine, W. E. The Expanded Vine's Expository Dictionary of New Testament Words. Minnesota: Bethany House Publishers, 1984.

Wagner, C. Peter. Gereja Saudara Dapat Bertumbuh. Malang: Gandum Mas, 1990.

Gandum Mas, 2005.

Manfaat Karunia Roh, Cetakan kelima. Malang: . Memimpin Gereja Anda Agar Bertumbuh. Jakarta: Harvest Publishing House, 1995. 1996.

Warren, Rick. Pertumbuhan Gereja Masa Kini. Malang: Gandum Mas, 2003. 